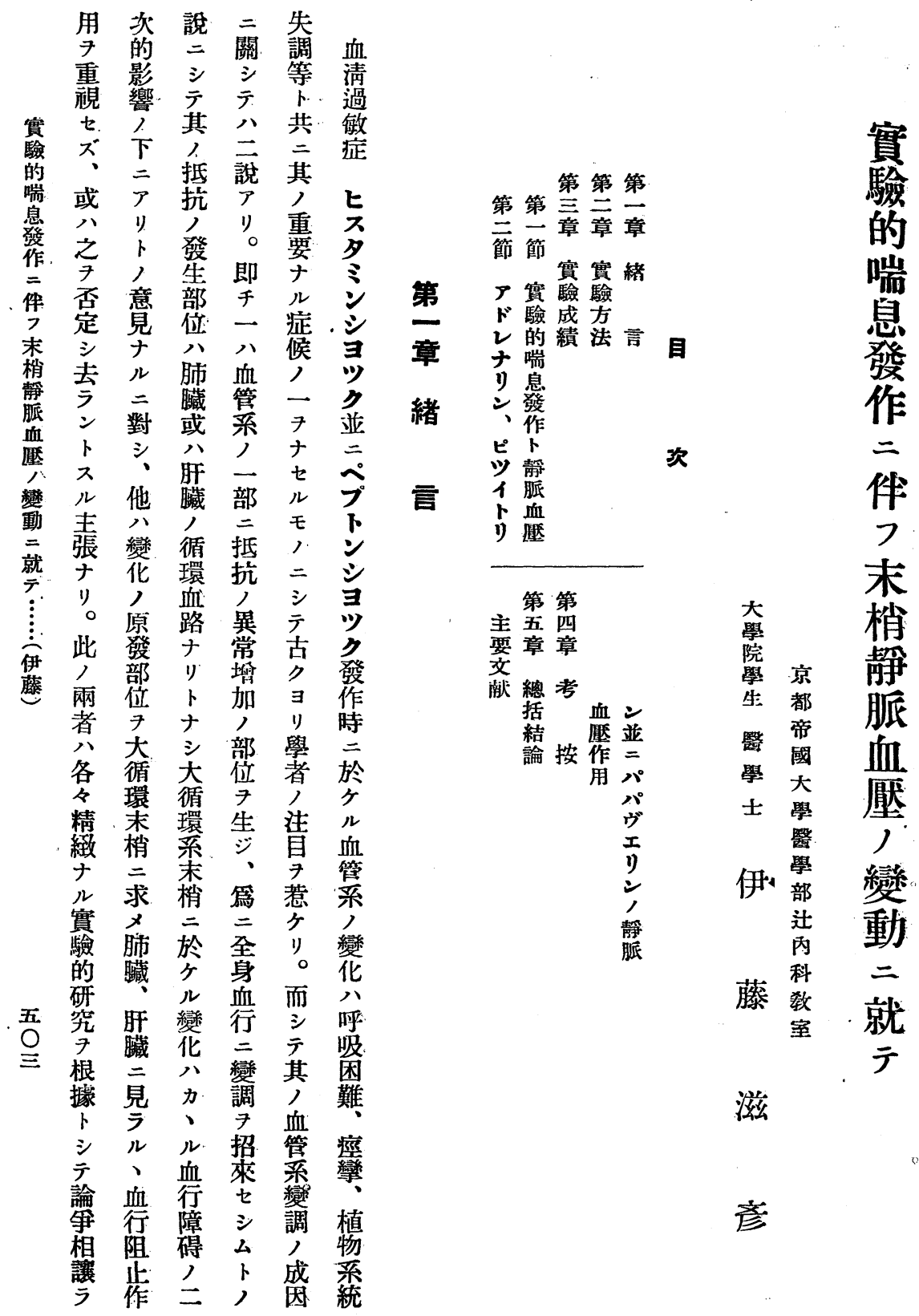



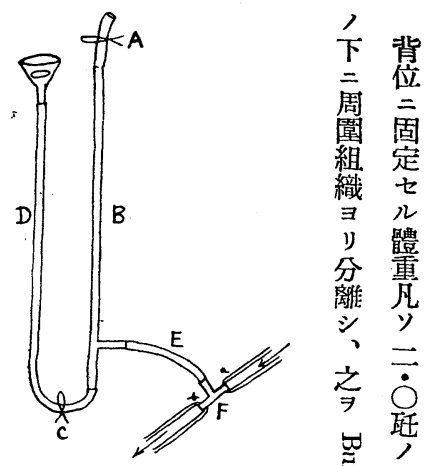

リ體

分箽

離 凡

之

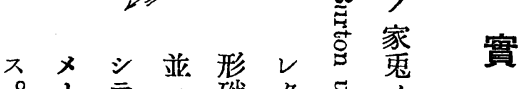

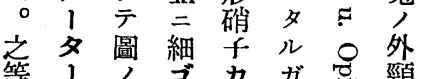

等 $1 ノ$ カ カ ガ 总頸

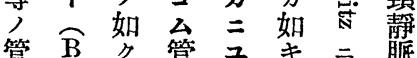

离 水 $\stackrel{\mathrm{E}}{\mathrm{E}}$ 細記

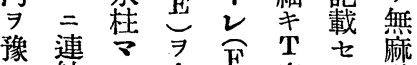

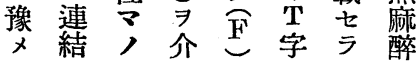

部所 儿通心碍血二

位謂高梁部 ス 少

血梢二流定事子票

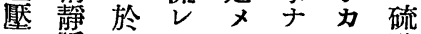

复脈

上血停, レ 0 之.

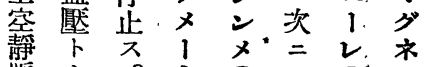

䰤古

右七其 リ

房。䜋 液開 1 二溶

開一品面力夕邉 液

口般 $\Rightarrow$ 八 1 a

部 $=$ 以 $\mathrm{F}$ 然, 资

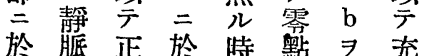

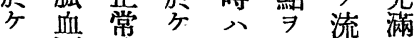

ル蕰時 几 管凡通セ

血八猙靜呙 ソ シ

臨慣脈脈, 家自メ

贸 側側、液 鬼然置

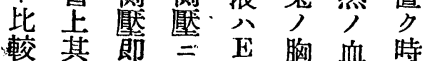

セ， 相、蔁行少

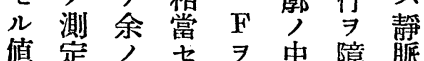

$\begin{array}{ccccccc}\text { キ 伴 } & \text { 行 サ } & \text { 由 } & & \text { ズ } \\ \text { 觀 } & \text { ヘ 變 } & \text { キ } & \text { ス } & \text { 然 } & \text { 今 } \\ \text { 祭 } & \text { 調 } & \text { ニ } & \text { ル } & \text { 日 }\end{array}$

セシ 二家事 二 二

ルヨ對兔, 最至實

モ

了於導此”。的

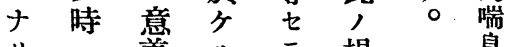

》三義ルラ場䁶

於䘫レ何ン 合籃

肺 小占見件

阻サ辛り

止テン シ.ル 末

作才的寻、梢

用キ檢严呼、䝑

二、索夕吸、脈

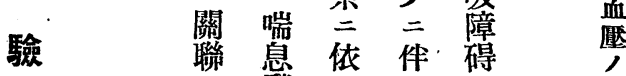

シ 發り 7 ガ 戀

穴作 シ 血 氣動

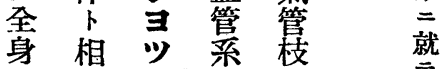

血伴 ク喘

行 人 時 變 息

八ル二化症

變 點 於, ,

化 = テ 攻 發

, 大八究作

一ナ常 八

斑 ル二更其

7 興 肺

窥 味 血 新 發

知子行子生

七有阻 ル 機

ン シ 止 興 制

卜夕作 味

人用卜同

意キ, 意

圖。存義 ウ

市本害年占

二驗 $尹$ 有 共

末確 ス

梢力認心肺

静、

脈 ル、至 管

血呼之方,

壓、吸 ガリ變

鉒。化

變 難 身 余

動 $\Rightarrow$ 血 公 

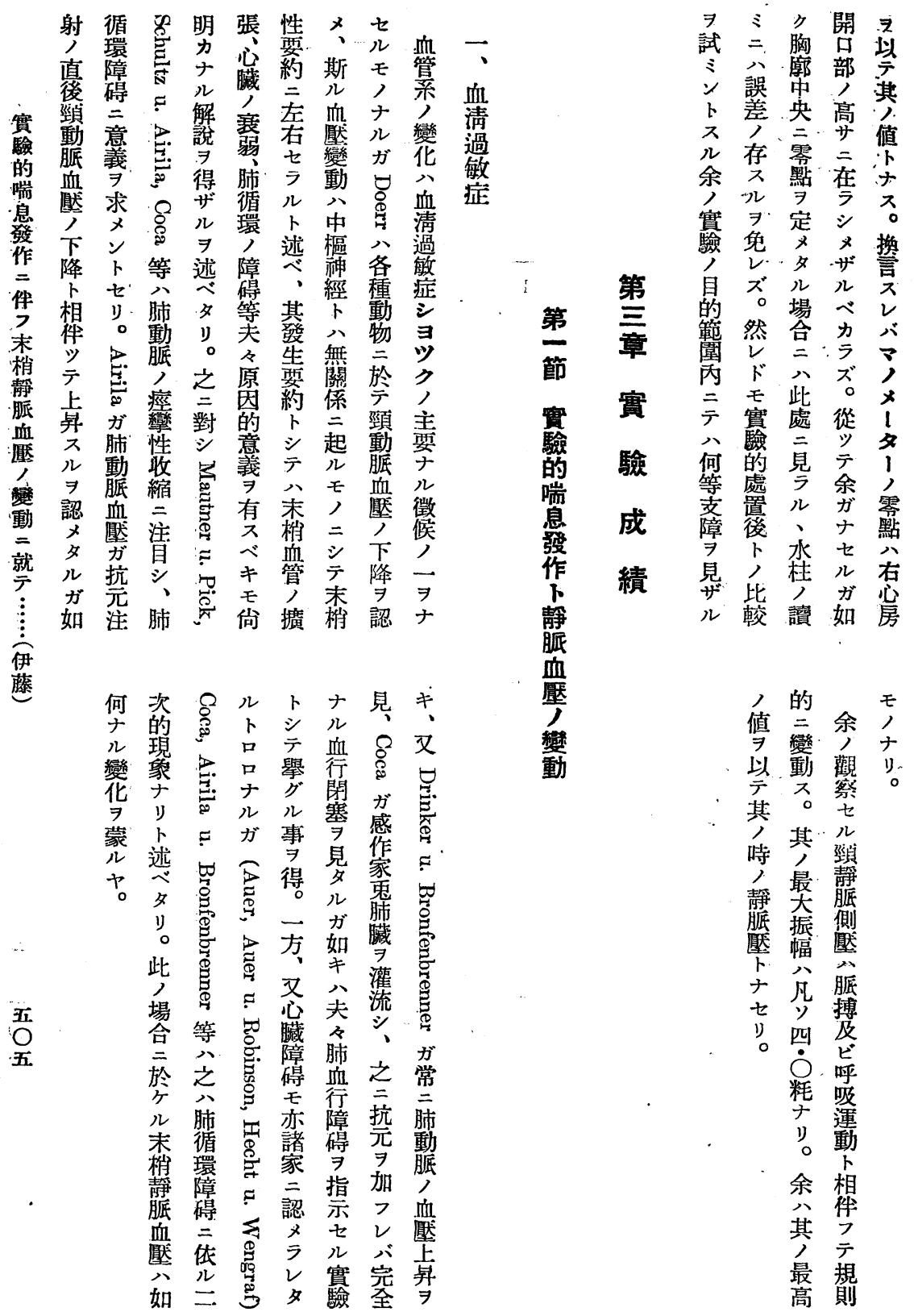


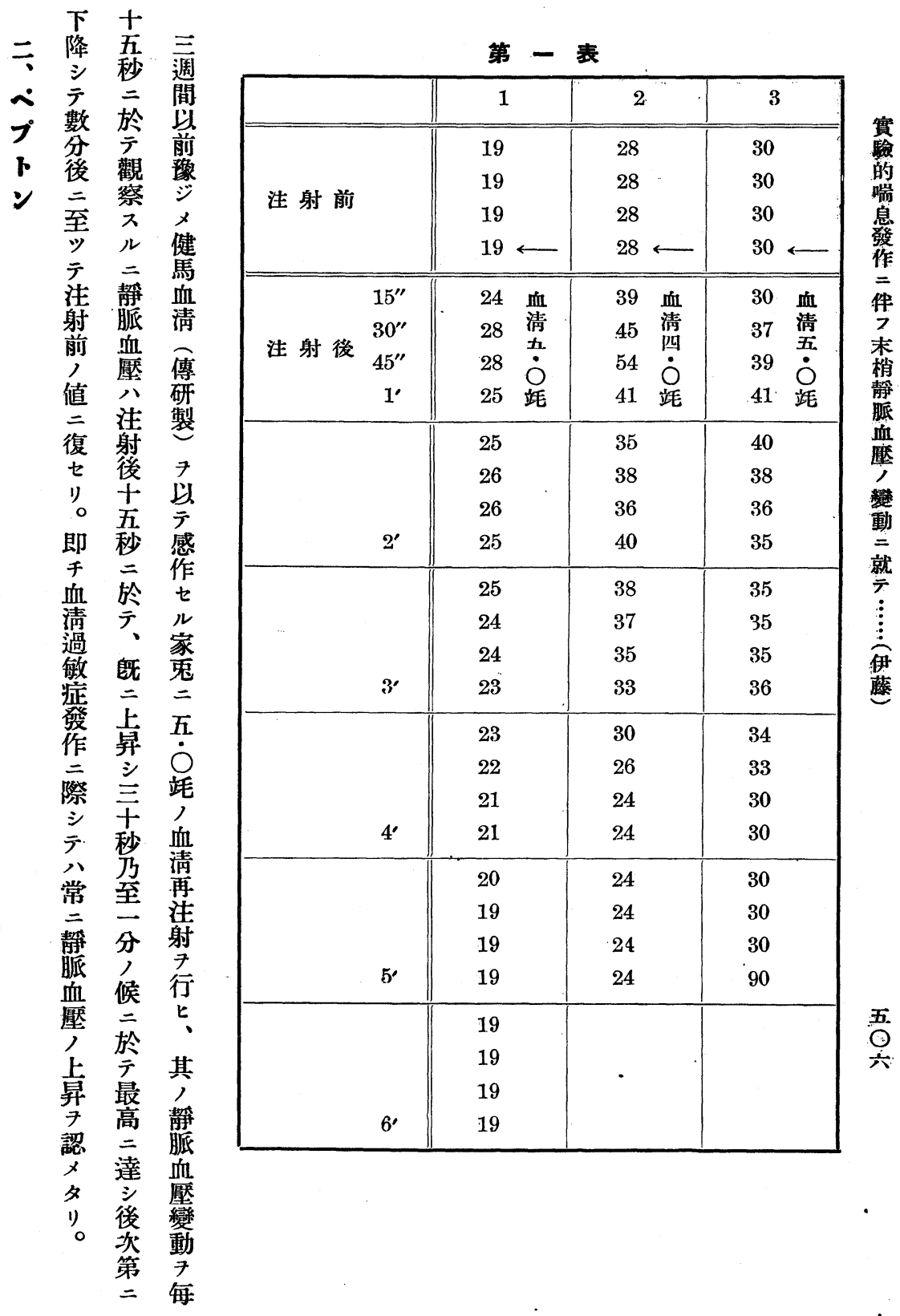




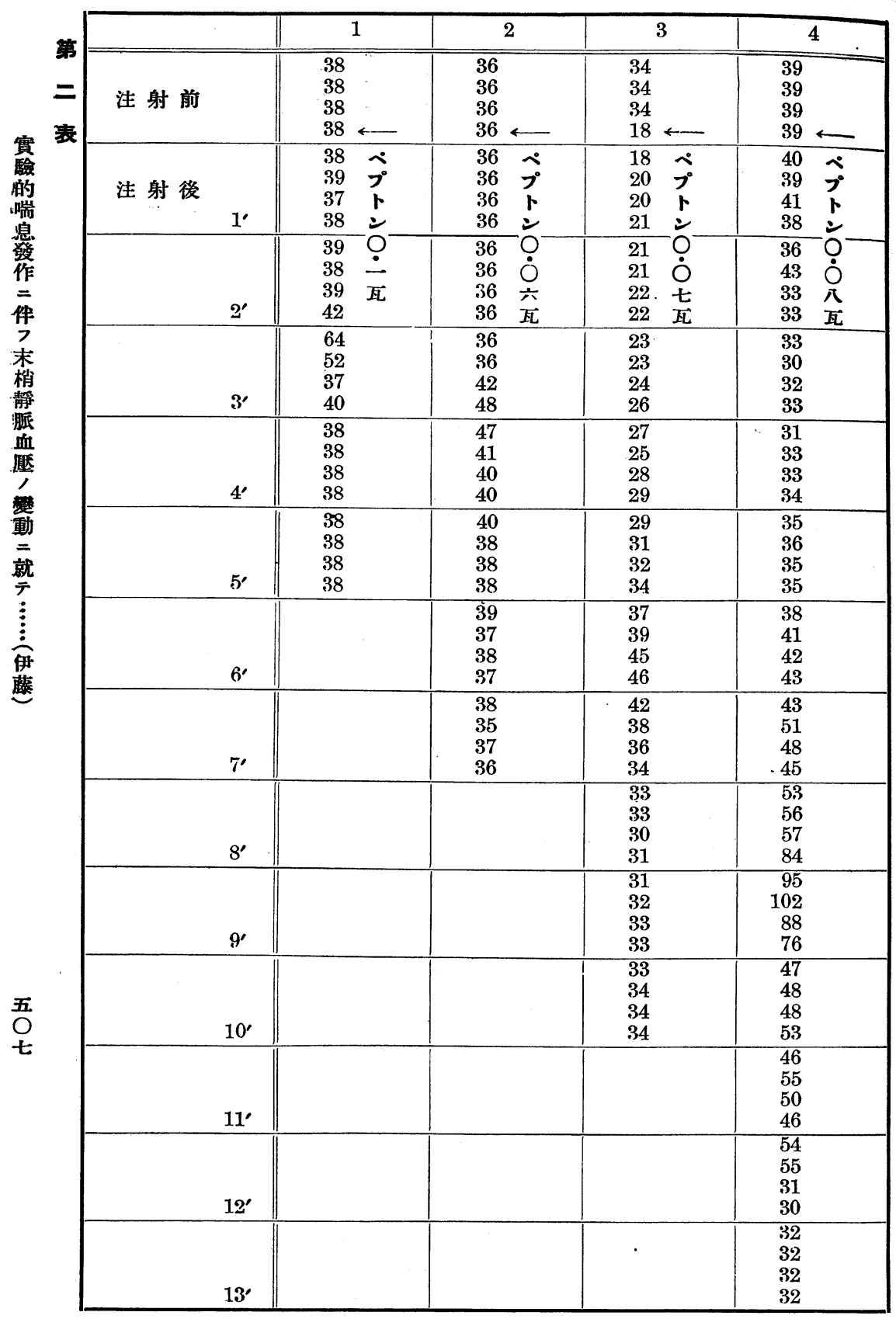


其 搖…動

フ 八

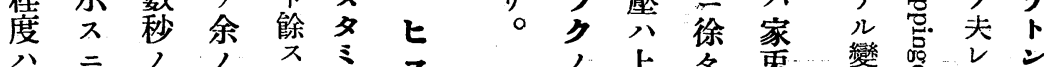

家至

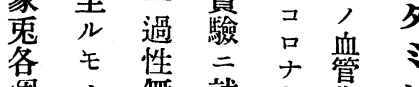

個ノ無就キ㤰

二ナ 呼 テ ガ 百

リガ 光紗

樣靜夜

樣靜淺一秀

ナ 脈 小 $\vec{\bigcirc}$ 㢣 後

ザ 厴吸 ○省,

ル八, 0 如

毛之後倍卡精

最相忽步

卡伴然多其文

昇上亲学嫯

水卡云溶血

柱昇定液

七 7 型

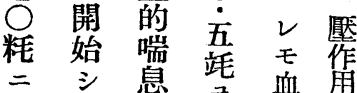

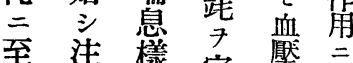

至洼樣 家 獎

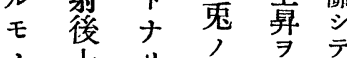

人只年認示

》吾腹静 品既

。秒脰脈名二

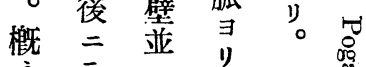

京整忩除

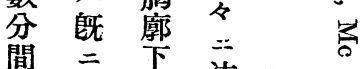

間 二 下 注

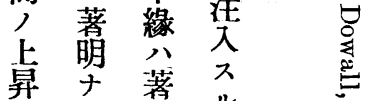

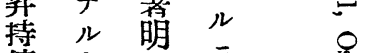

續奌 ル 其迸

後寻呼

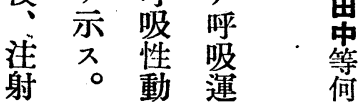

狀 注於公極寻

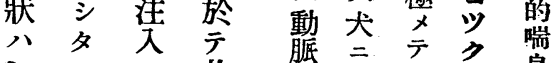

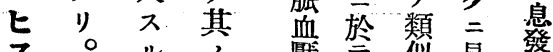

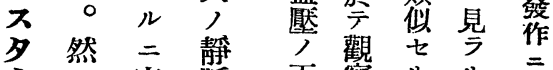

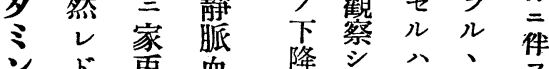

ンド兔血降产㵔血

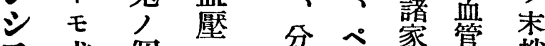

$\exists$ 或個) 分

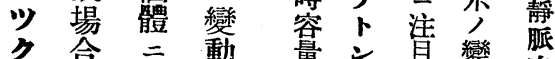

, $\exists$ 量主紗血

症八川觀三寻

比壓少 七 篮時儿主動

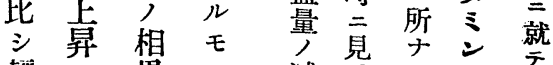

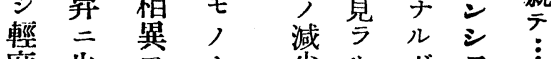

度先穾ナ少ルガ寻

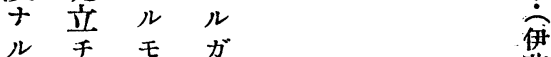

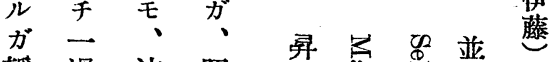

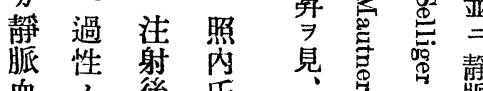

血血後 數

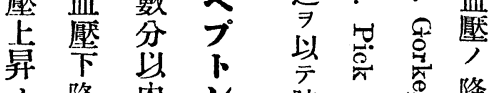

了降內

度 時於 - 歨頸

亦学\% 俑锤蜜認

步

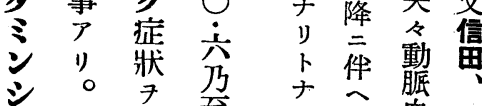

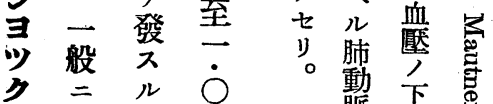

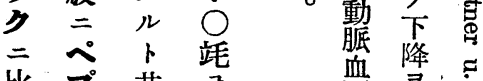

比 プ 共 等 奥

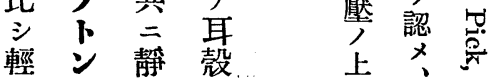




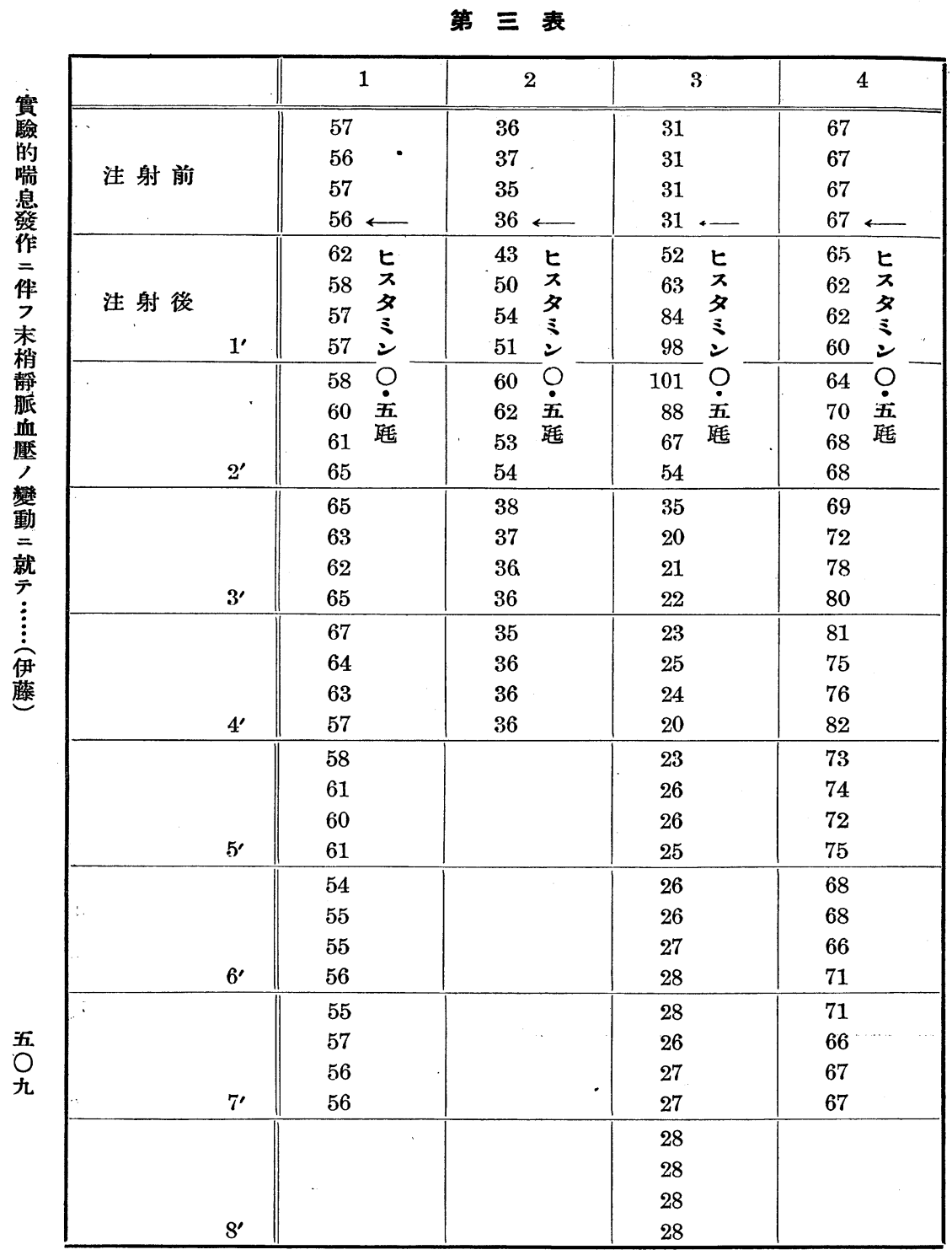


第 四表

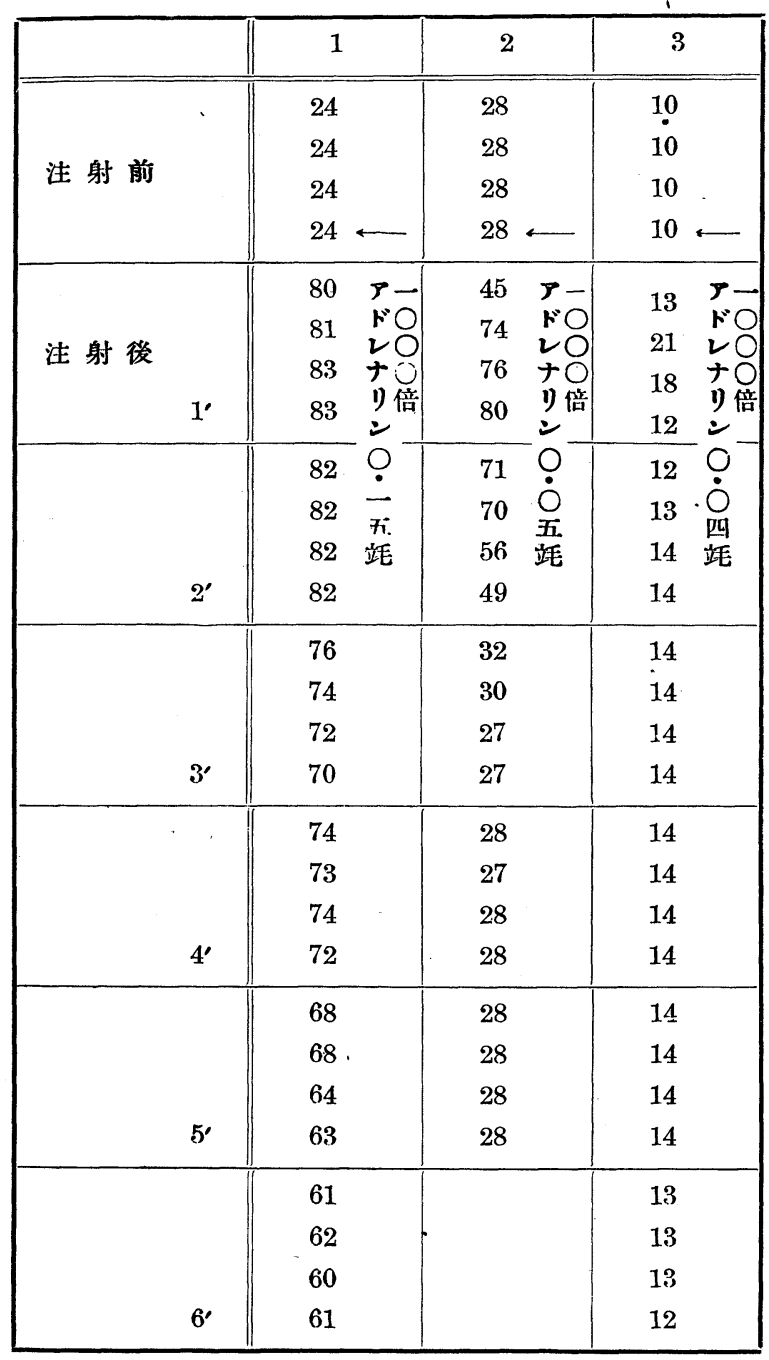

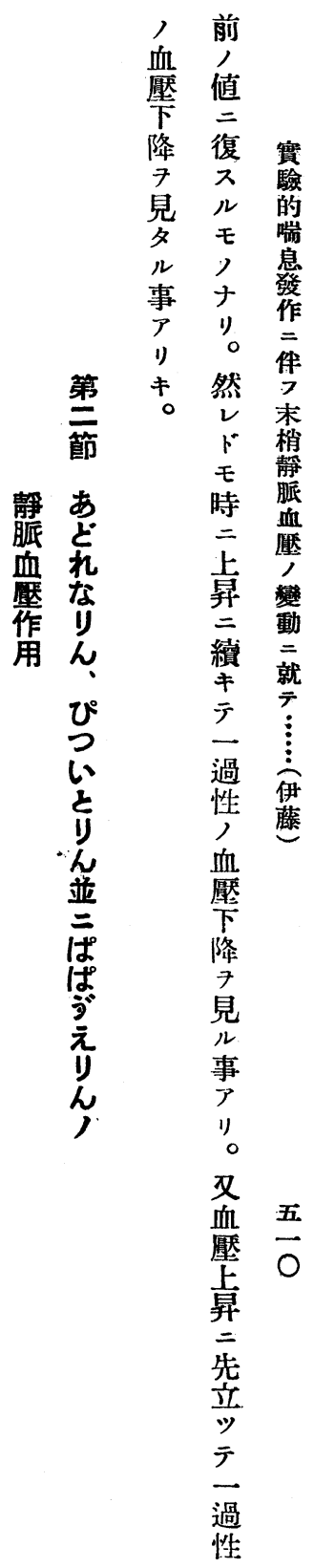




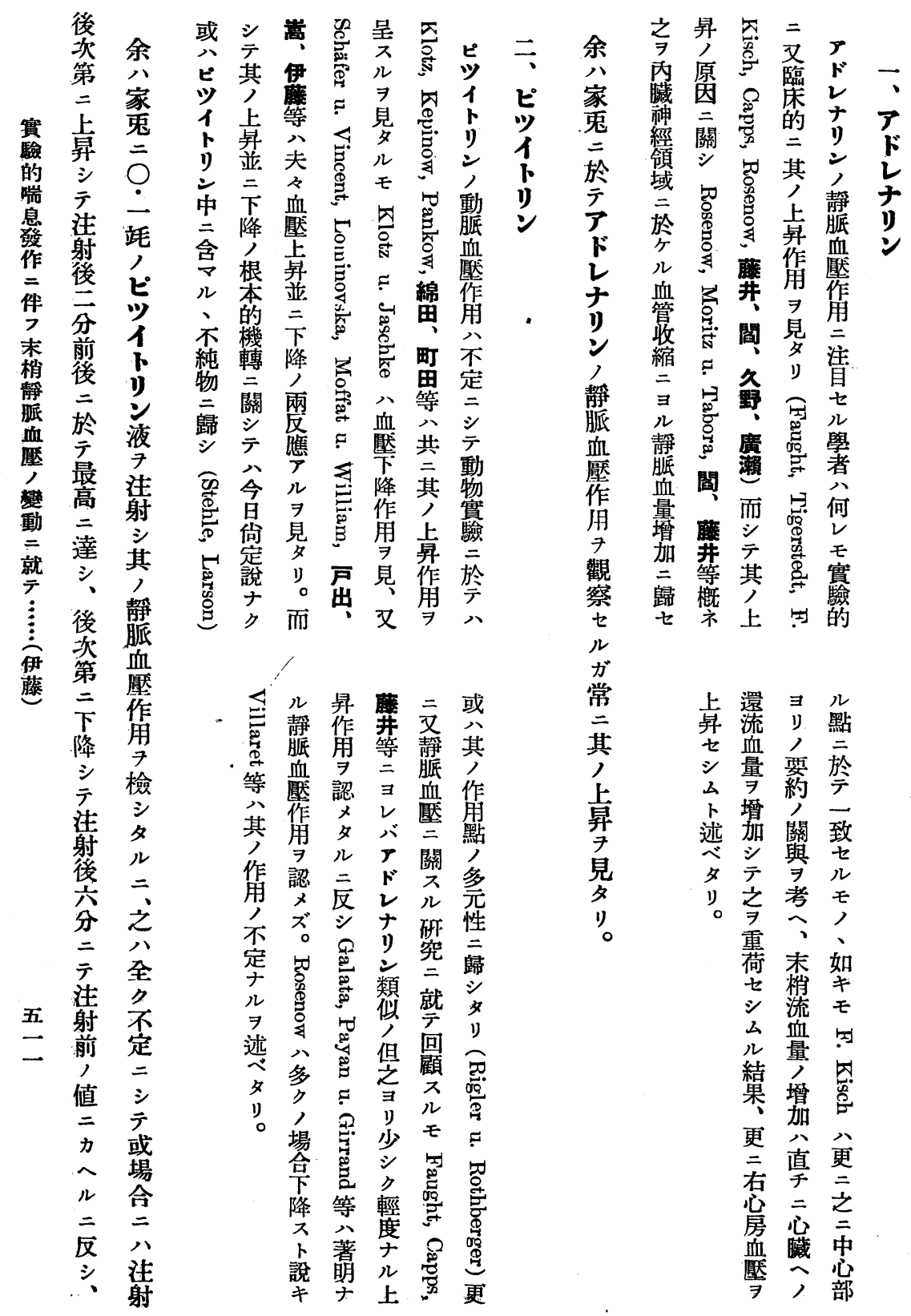


第 五 表

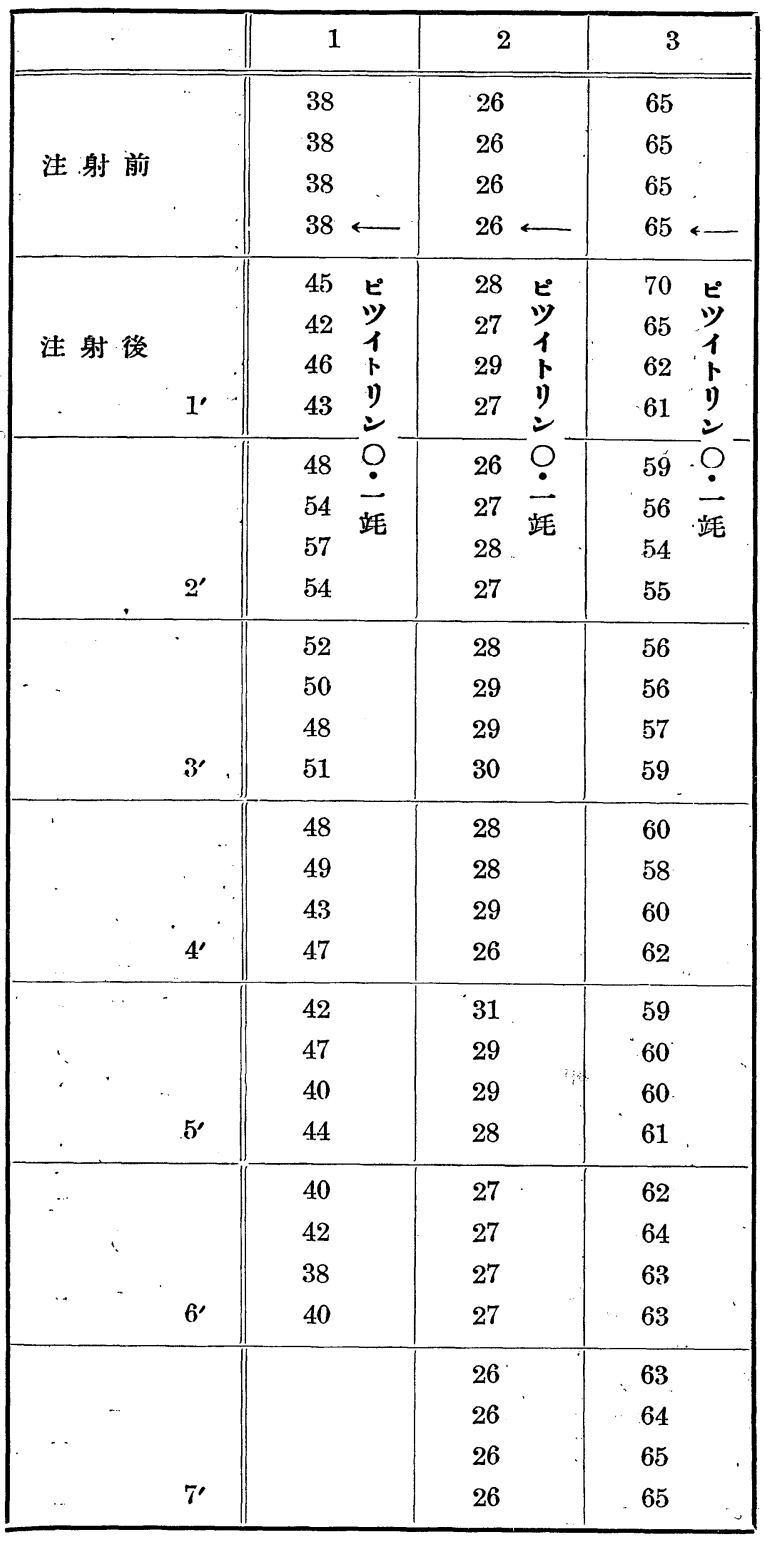

射 前 苛場

八 '合

値注

復 䠴 其

七尖

门市点喘

梨昇鼻

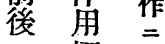

於極伴

テテ 末

一 輕. 梢

過 度 静

性 三 脈

方 血

占約變

示

七内就

儿外

後 三

直 過

干ギ伊

二ズ 藤

下

降 六

，分

傾 內

向 外

7 了

卜 持

リ 續

爷 後

分 射

至 前

八, 五

分 值 二

前 $=$

後 復

人 歸

下 的

降 更

續 二

，他

後,

注 例 


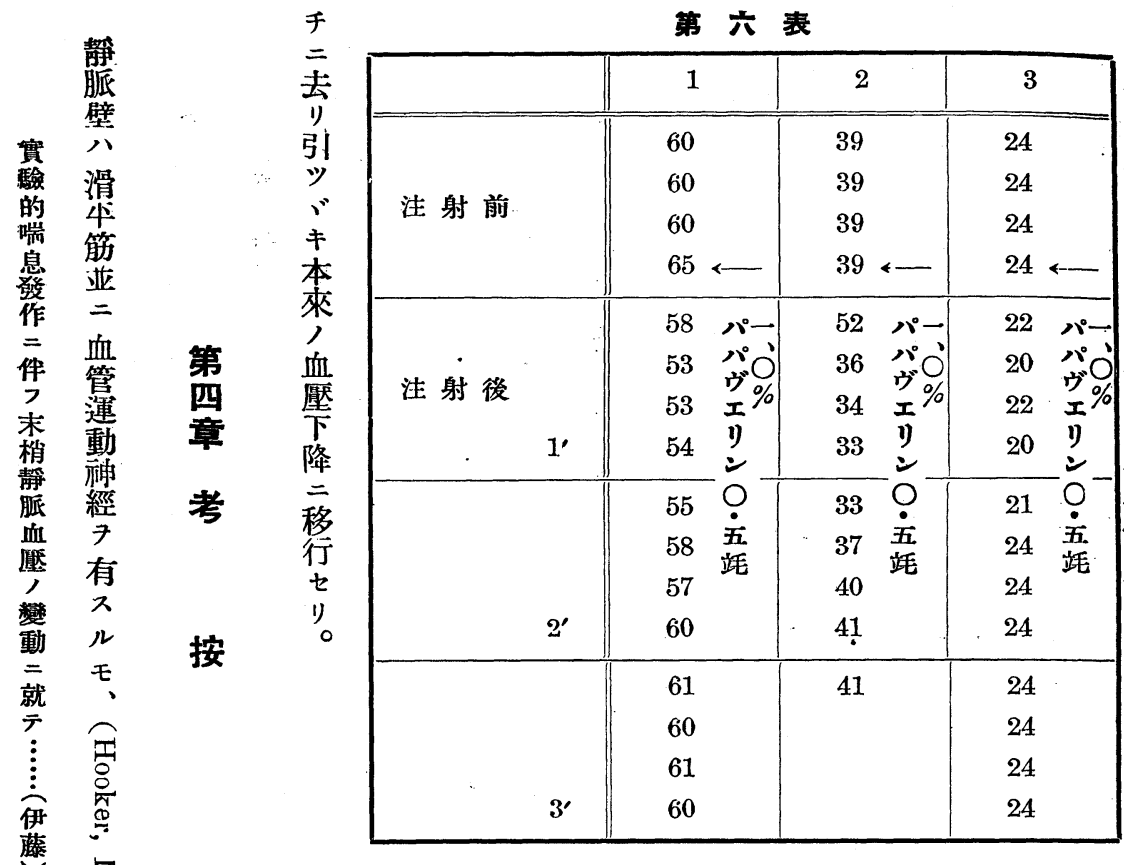

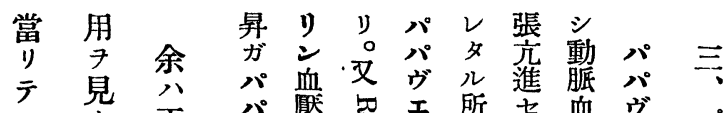

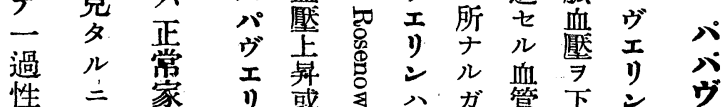

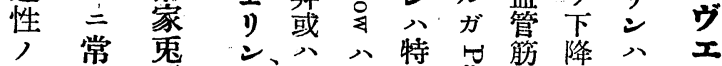
血二敖 三血末

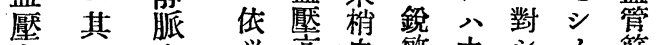

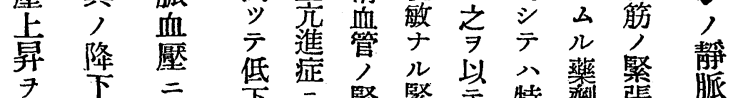

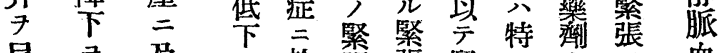

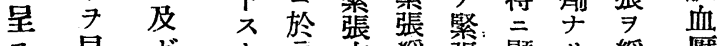

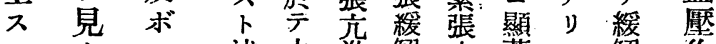

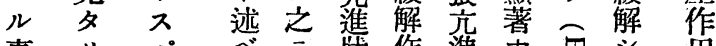

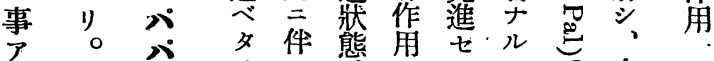
血.

壓

主

主 


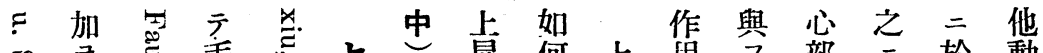

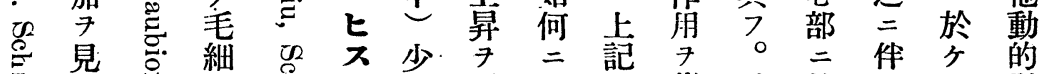

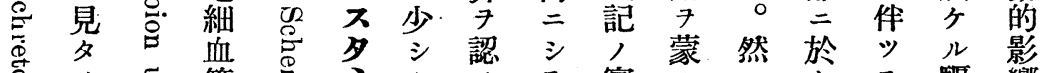
一宫

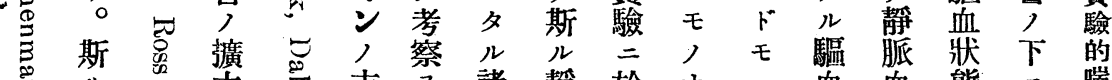

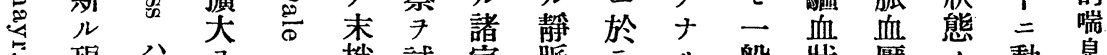

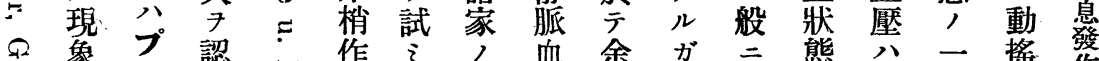

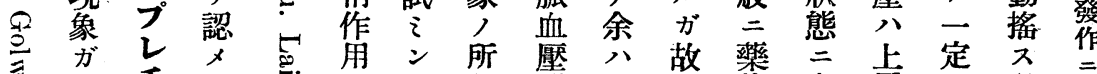
紊果手

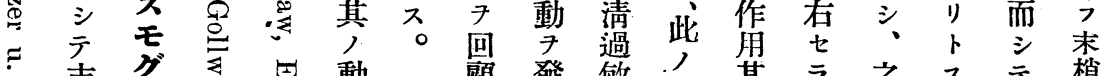

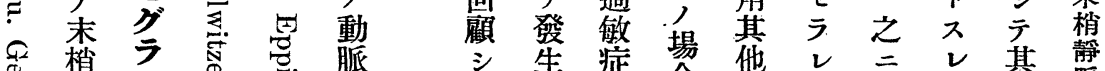

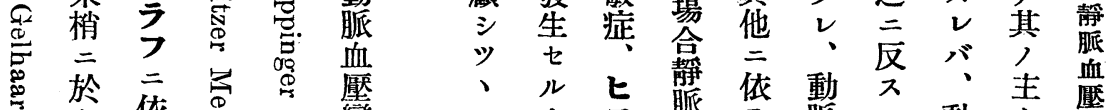

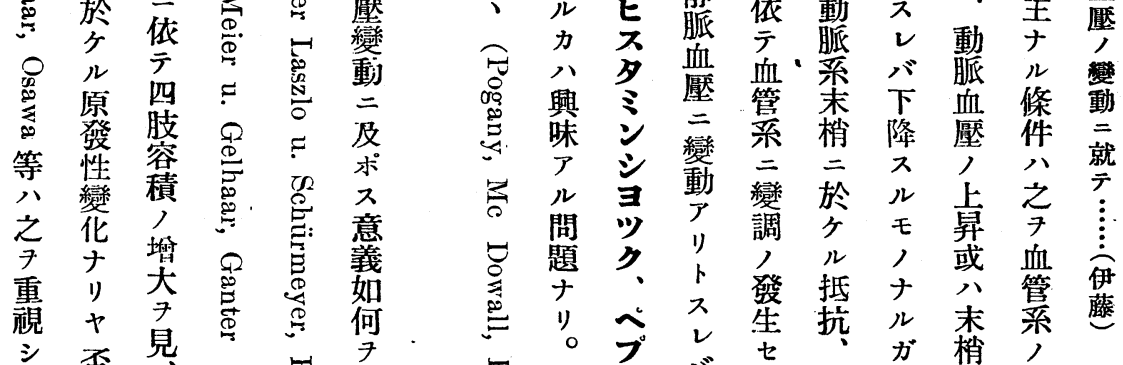
否見

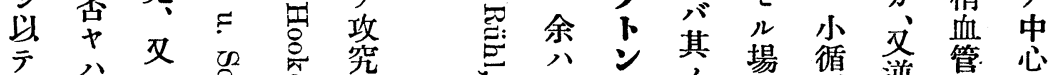
動今

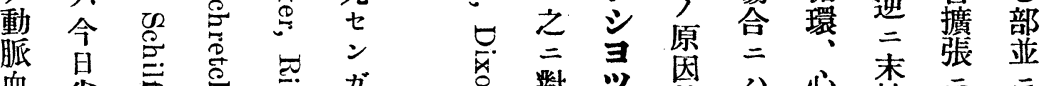

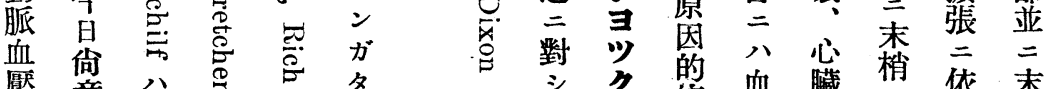

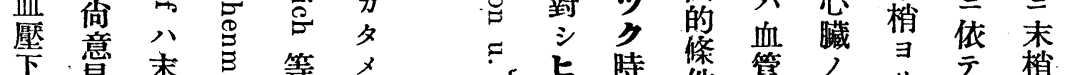
降見梢总等 機 致管 等

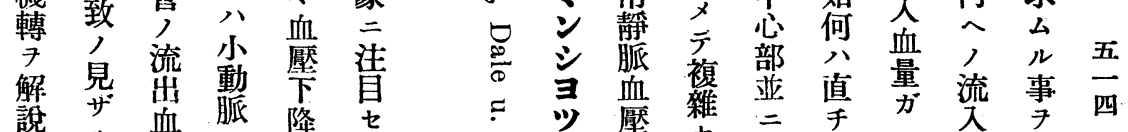
說 ザ血脈降落 七所量度動

ン所量擴物 レ

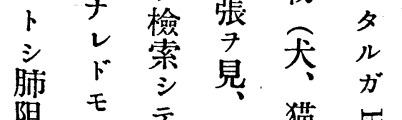

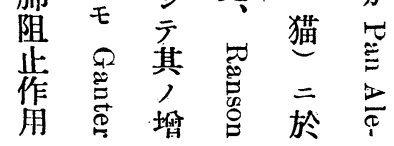

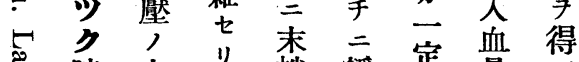

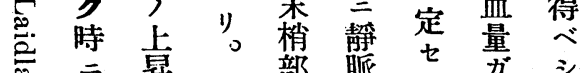

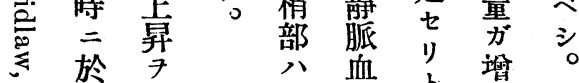
○罢 概壓

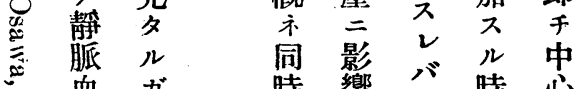

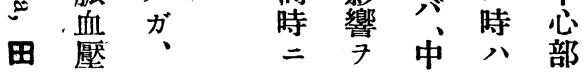




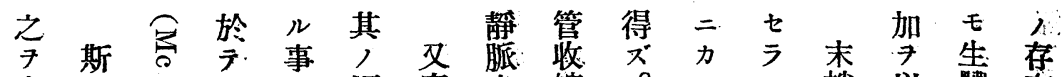

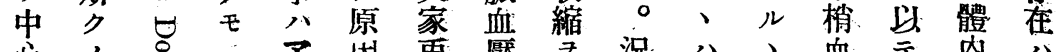
心

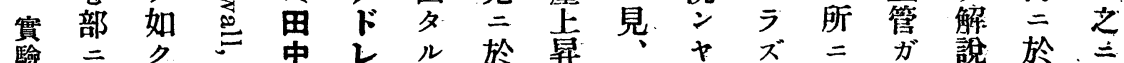

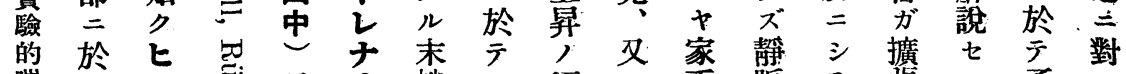

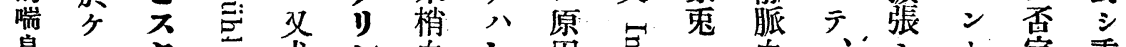

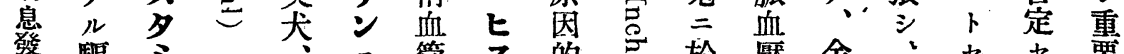

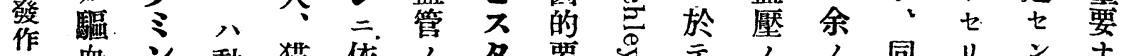

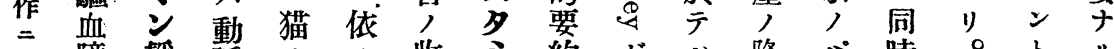

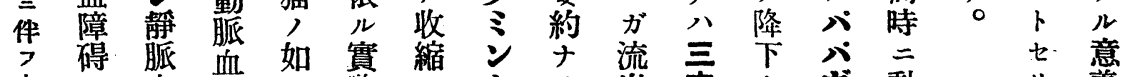
末二血厴 $\neq$ 駿 梢求壓占動二依寻卜量、三王脈

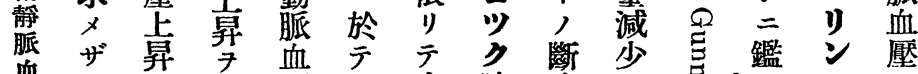

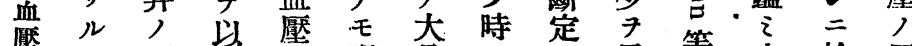

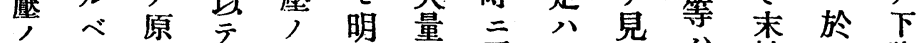

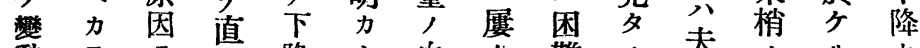

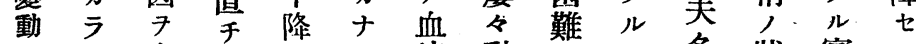

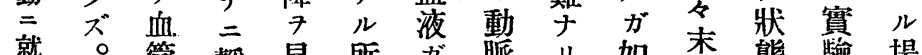
就。管静見所分脈 リ如条態驗場

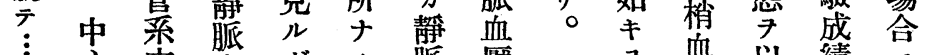
$\vdots$ 心息 ガル脈壓 篮 以績

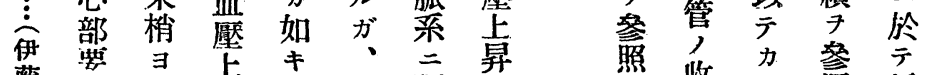

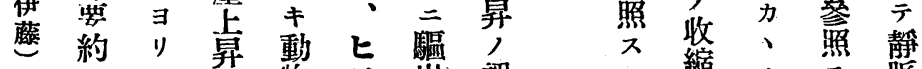

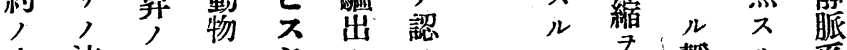
主流原二タ七メ兵靜ル采 十血圌於令 $ラ$ 於見脈二 ル量ナテテンル モ墔り $モ 二$ 靜、 , 加卜 共 對 脈 モ 八 心求 $九$ 靜 $テ$ 血 臟么 7 脈 八量 シ 機 ル 得血動 7 、 能事 希 壓血垢增

五胸困长壓 害

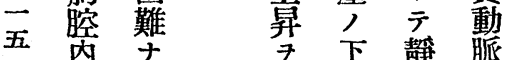
壓り，見降脈血 亚 $ト$ 合 壓 二ス, ル壓,

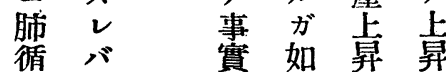
環、 ナ吾鑑家發ル 少人总冤生時 時 $=$ 公

テ, 血此,

八壂, 流 更慰場 入 二昇合 血 七导, 香夜 万八原梢量 夕七因擴 弪卜張增 ン夕大亚・加 $=\$ \pi=\pi$ 依 $ン$ 血 ル 几至檿 末 動 難 降 否

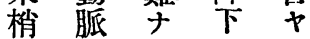
流内少 血洼卜染大 量 射考 想 1 人 $=\hat{t}=$ 增 依 ザ う 疑 加示ルル問 $\circ \%$

而 有 シ セ

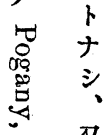
条 觢

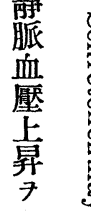
モ

力 , ル 末 肺 梢 阻 血步 擴 角 張 y $\exists$ ル, 流 血 存 量 在 


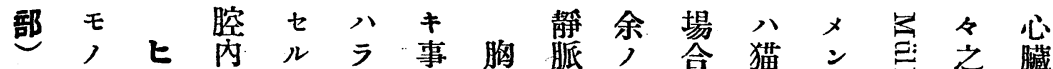

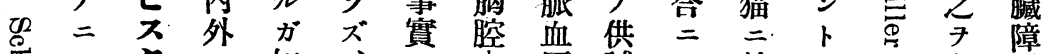

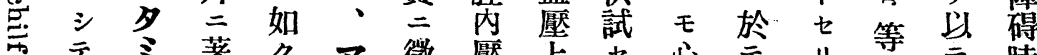

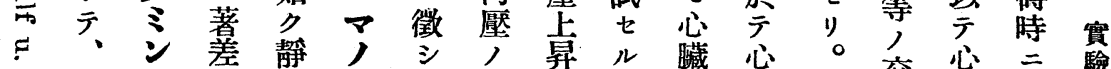

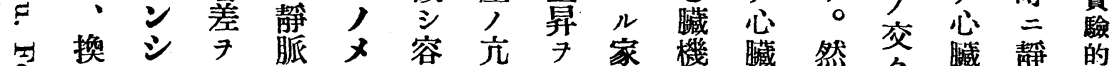

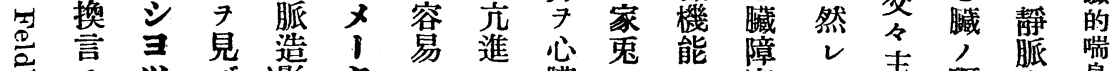
总少

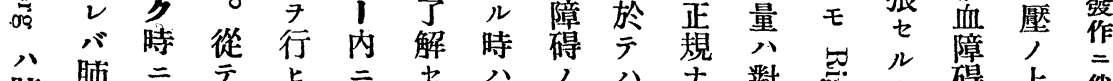

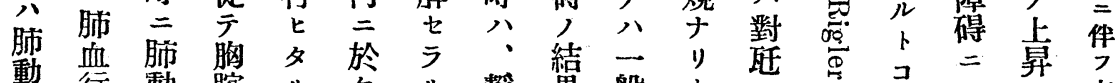

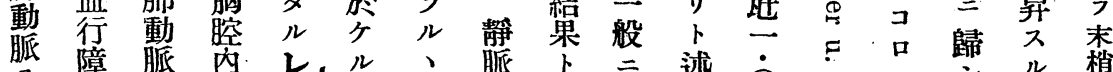

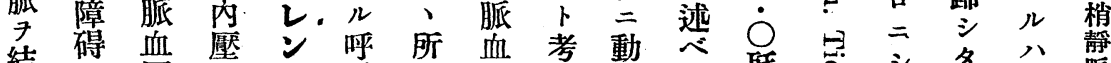

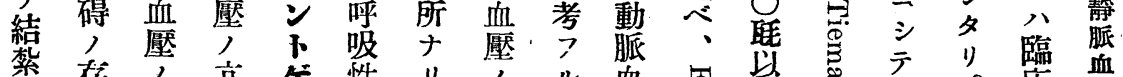

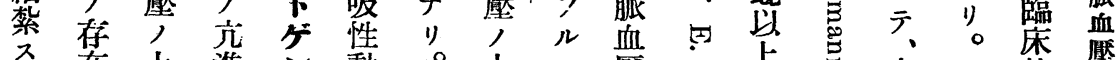

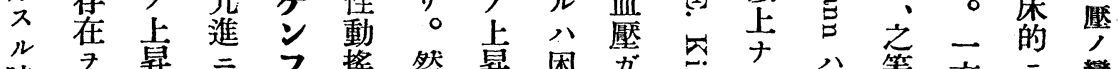
時 7 昇二物

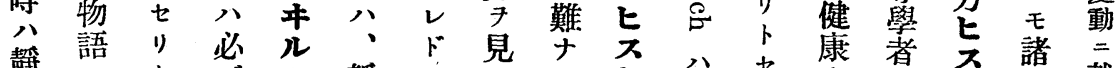

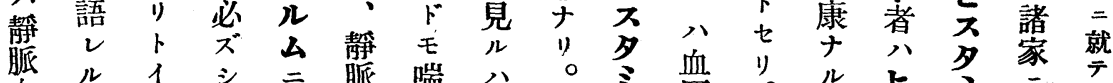

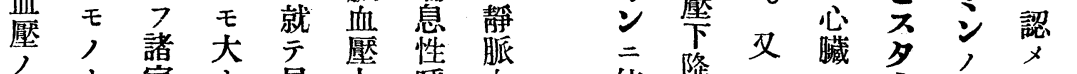

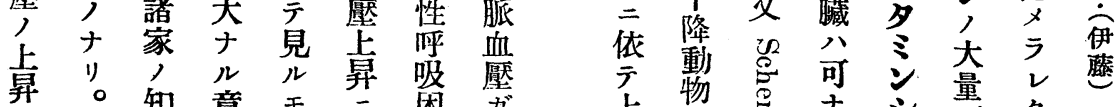

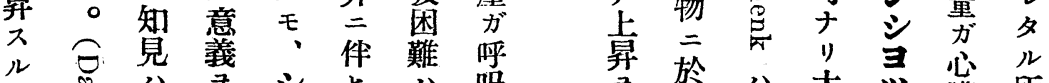

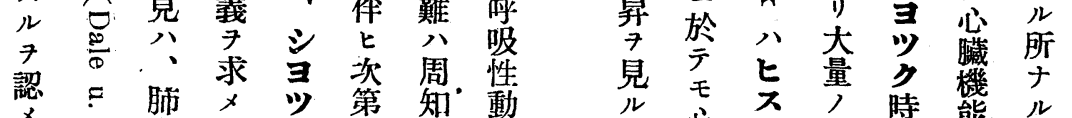

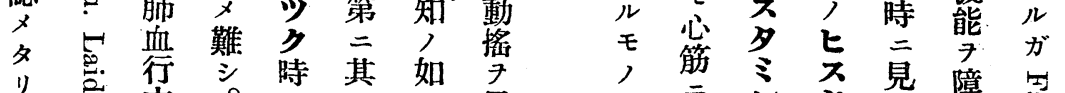

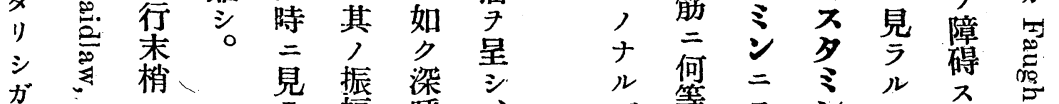

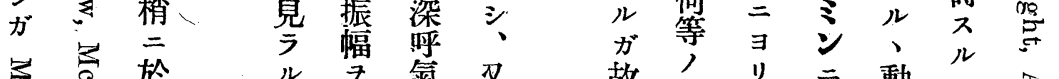

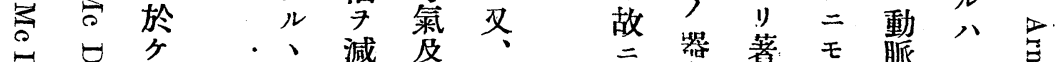

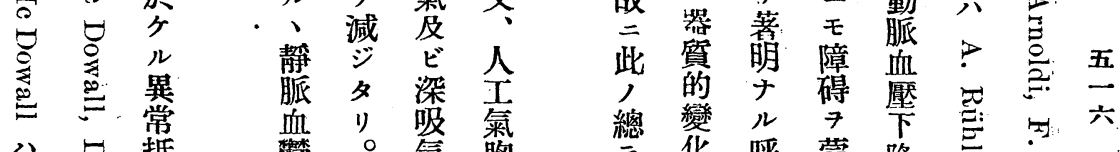

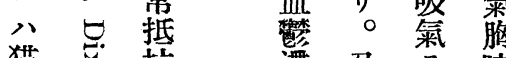
猫范垫潘及类時

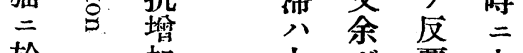

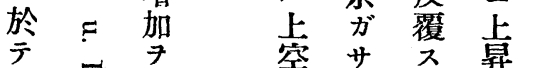

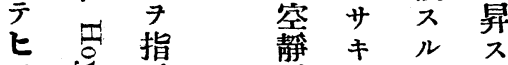

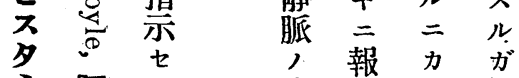
尽阿 $几$ 胸䇤、如 厂华呼蒙降巨

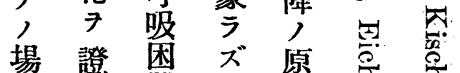

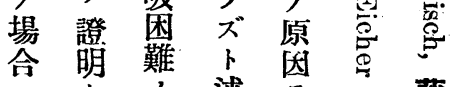
妿, 避籍 皃蓄發穴此相

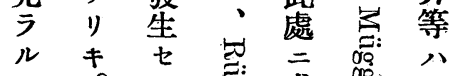

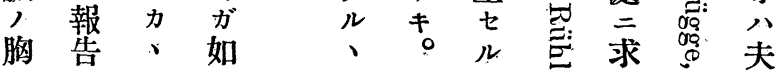




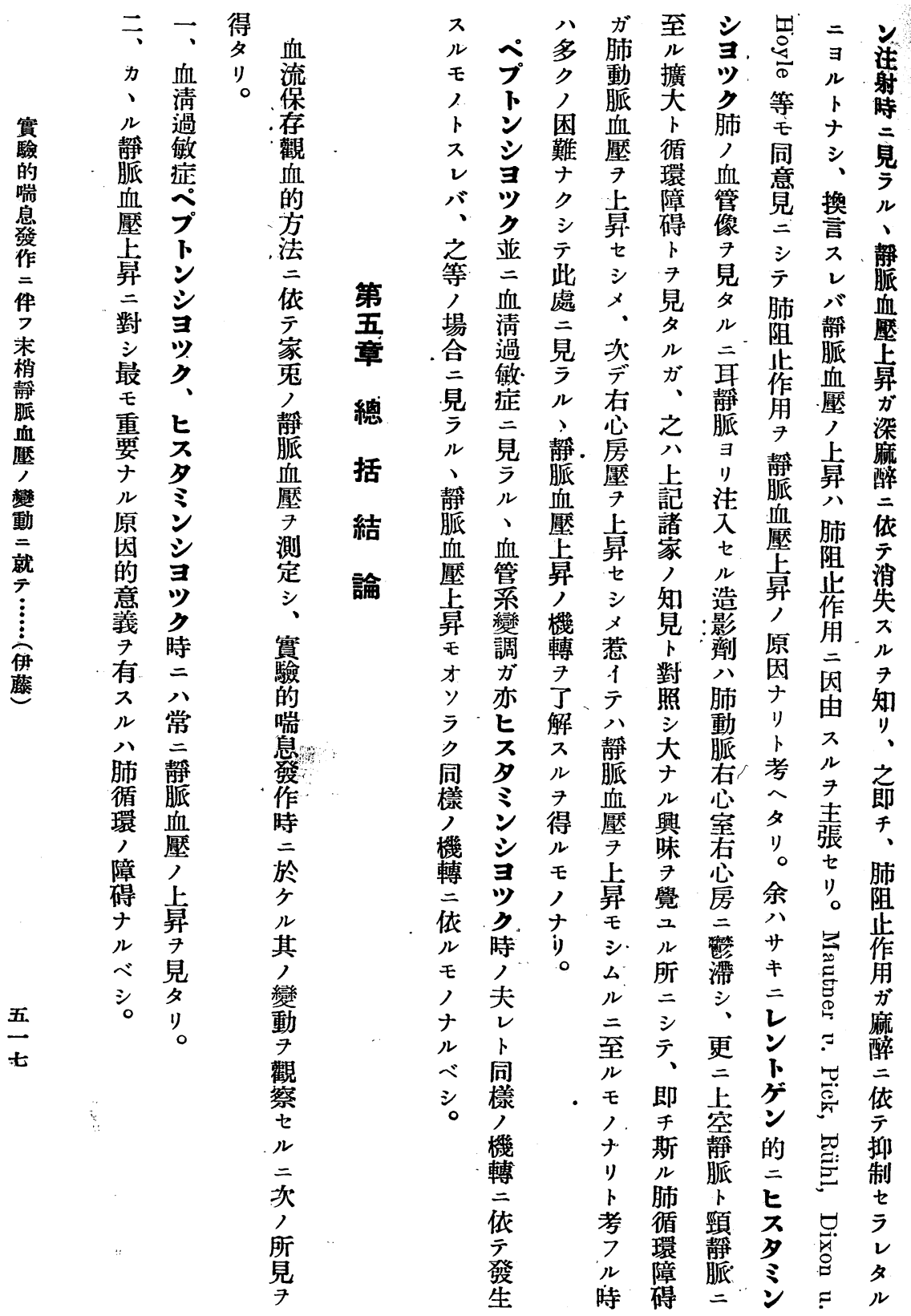




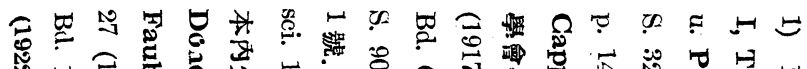

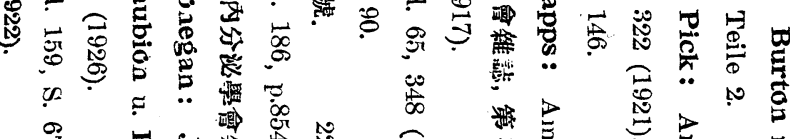

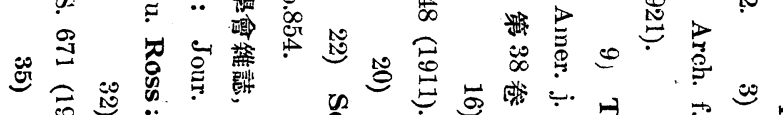

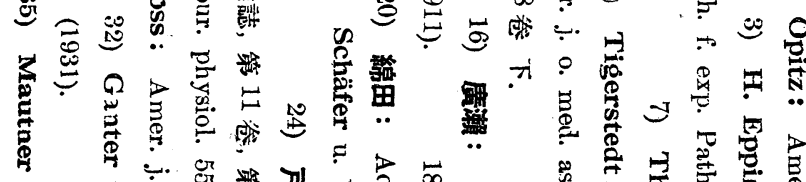

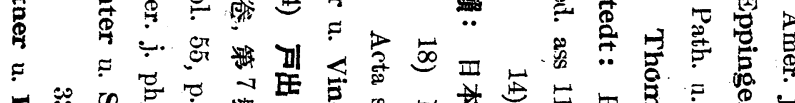

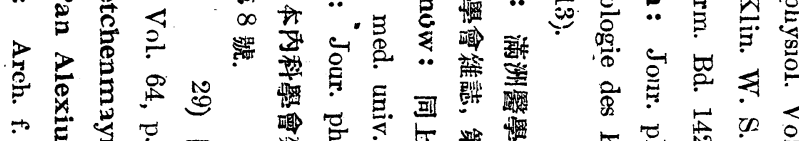

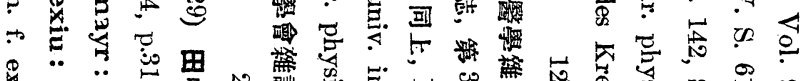

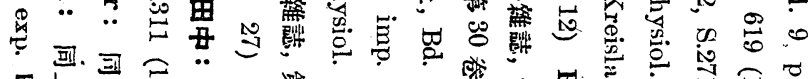

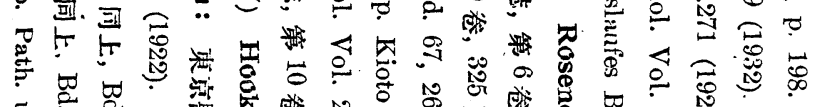

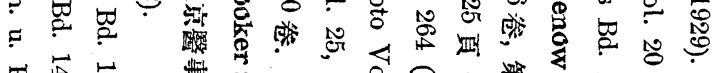

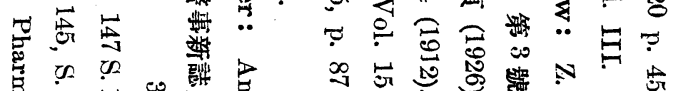

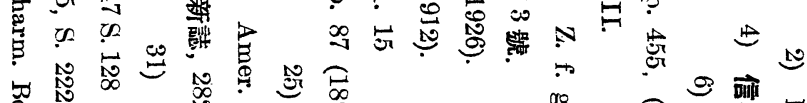

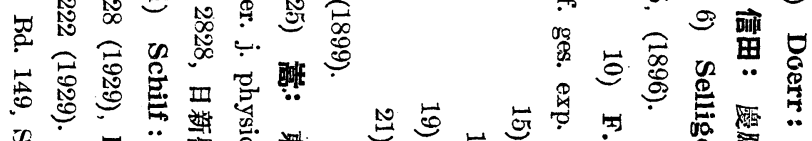

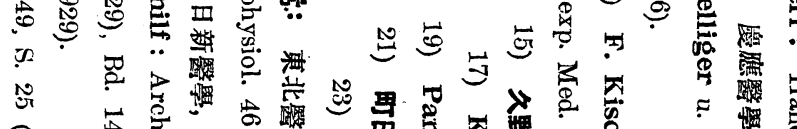

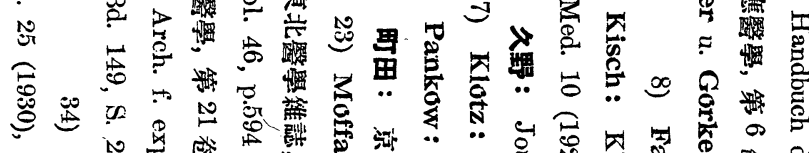

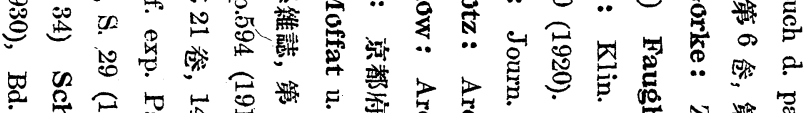

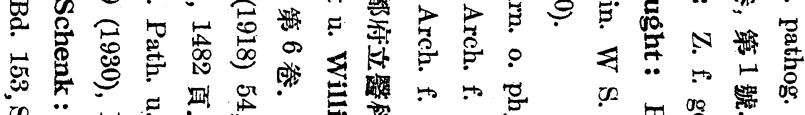

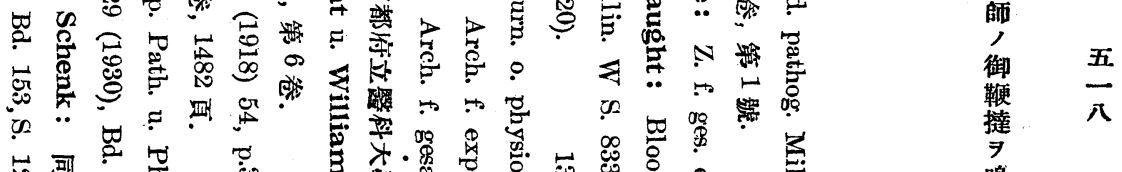

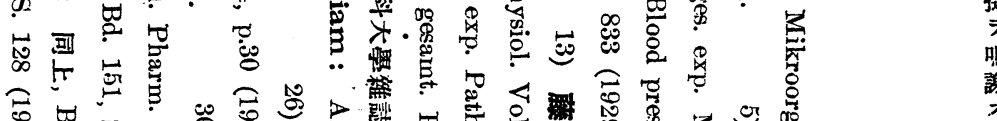

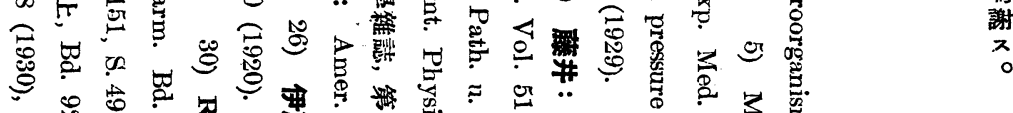

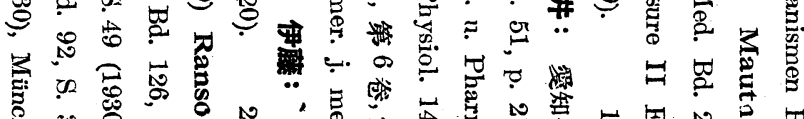

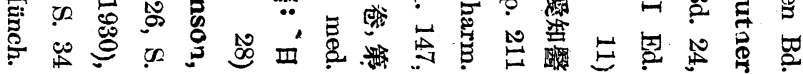

何 㧩

本 筆

論 ス 實

交 $n$ 驗

要 $=$ 的

昭終睩

和始 作

十想的

年篤华

月 $n$ 末

第 御梢

茴指督脈

日 $卜$ 血

本御型

分閱戀

泌 7 動

學 賜=

會 》就

會，

席 恩

上師伊

於䔔藤

厂 授

之心

報 謝

告 シ

り併

$\bar{T}$

$\equiv$

宅

撞 
Der Verfasser untersuchte beim Kaninchen den Einfluss der Injektion von Luminal- $\mathrm{Na}$ und des Gynergens auf die durch die Injektion des Zwischenhirn- $\mathrm{NaCl}$ - extraktes, die Injektion von Calcium sowie von Zwischenhirn- Alkali- extrakt hervorgerufene Blutzuckersteigerung.

Die Resultate waren die folgenden :

1) Die Blutzuckersteigerung durch Calcium wurde durch Luminal $\mathrm{Na}$ nicht beeinflusst, während die durch Gynergen gehemmt wurde.

2) Auf die Blutzuckersteigerung durch Zwischenhirn- $\mathrm{NaCl}-$ extrakt wirkte Luminal- Na nicht oder verstärkte sie leicht, während Gynergen sie abschwächte d. h. die Einwirkung des Zwischenhirn$\mathrm{NaCl}$ - extraktes auf den Blutzucker war analog der des Calciums.

3) Die Einwirkung des Zwischenhirn- Alkali- extraktes auf den Blutzucker unterschied sich von der des Kochsalzlösungextraktes so gut wie nicht.

(Autoreferat.)

\title{
Über die periphere Venendruckschwankung beim Kaninchen mit experimentellem Asthma.
}

\author{
Von \\ Dr. S. Ito.
}

(Aus der I. Med. Klinik der Kaiserl. Universität zu Kyoto in Japan Direktor: Prof. Dr. K. Tsuji)

Der Jugularisvenendruck des Kaninchens wurde mittelst der Tförmige Venenkanüle und des mit dieser verbundenen Wassermanometers blutig gemessen. Während des experimentellen asthmatischen Anfalles stieg der Venendruck stets an.

In der vorigen Mitteilung bemerkte der Verfasser an den asthmatischen Kaninchen röntgenologisch eine merkwürdige Lungenzirkulationsstörung, die bei dem Venendurckanstieg eine grosse Rolle spielen muss.

(Autoreferat.) 